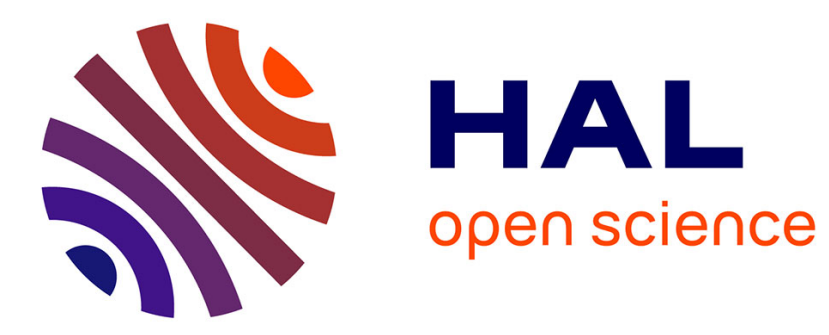

\title{
A dynamic biofilter to remove pathogens during tomato soilless culture
}

Franck Déniel, David Renault, Yves Tirilly, Georges Barbier, Patrice Rey

\section{To cite this version:}

Franck Déniel, David Renault, Yves Tirilly, Georges Barbier, Patrice Rey. A dynamic biofilter to remove pathogens during tomato soilless culture. Agronomy for Sustainable Development, 2006, 26 (3), pp.185-193. hal-00886353

\section{HAL Id: hal-00886353 https://hal.science/hal-00886353}

Submitted on 1 Jan 2006

HAL is a multi-disciplinary open access archive for the deposit and dissemination of scientific research documents, whether they are published or not. The documents may come from teaching and research institutions in France or abroad, or from public or private research centers.
L'archive ouverte pluridisciplinaire HAL, est destinée au dépôt et à la diffusion de documents scientifiques de niveau recherche, publiés ou non, émanant des établissements d'enseignement et de recherche français ou étrangers, des laboratoires publics ou privés. 


\title{
A dynamic biofilter to remove pathogens during tomato soilless culture
}

\author{
Franck DÉniel, David Renault, Yves TiRilly, Georges Barbier, Patrice ReY* \\ Laboratoire de Biodiversité et Écologie Microbienne (EA3882), ESMISAB, Université de Bretagne Occidentale-Brest, \\ Technopôle Brest-Iroise, 29280 Brest, France
}

(Accepted 29 June 2006)

\begin{abstract}
In tomato soilless culture, slow filtration is used to control the development of diseases caused by pathogenic microorganisms. We report a three-year monitoring study of the use of a "shier biofilter", which is a dynamic filtration system where the water and the filtering media, pozzolana particles, are maintained in constant motion by an air pump. We found that this biofilter removed more fungi than bacteria under tomato production conditions. The rate of efficacy against pathogenic fungi was genus-dependent. Indeed, against Pythium spp., more than 99\% of thalli were eliminated over the 3-year survey. But, against Fusarium oxysporum, efficacy fell within 92.7 and $99.3 \%$. Regarding the total cultured-bacteria microflora, despite a high elimination rate of $91.2-98.9 \%$ the effluent solution was colonized by large populations, from $6.610^{2}$ to $1.410^{4}$ colony-forming units $/ \mathrm{mL}$. The biofilter efficiency was found to be mainly related to the biological activity of the bacterial biofilm on the pozzolana particles. The high rate of Pythium spp. elimination by the dynamic biofilter was correlated with the low colonization of roots by these pathogens. Necrotic symptoms were only observed in September, i.e. at the end of the cultural season. By limiting the dissemination of pathogens and eliminating the root-fungi dynamic, filtration proved to be a helpful technique. It, however, preserved most of the bacteria driven to plants by the nutrient solution, which led us to discuss their potentially beneficial effect on roots.
\end{abstract}

Pythium spp. / Fusarium oxysporum / Bacillus / Pseudomonas / disinfection / root disease / recirculation

\section{INTRODUCTION}

Fungal diseases are a major problem in soilless cultivation of greenhouse plants because both yield and quality can be compromised. Irrigation waters from various sources such as lakes, rivers, open reservoirs and ponds may be sources of infection by pathogenic microorganisms (Stanghellini and Rasmussen, 1994). The use of closed soilless systems is attractive for growers because of cuts in water and fertilizer consumptions; on the other hand, they must be aware that their cultures are more at risk of root disease spread by pathogen fungi-producing zoospores such as Phytophthora spp. and Pythium spp. via the recirculating nutrient solution (McPherson et al., 1995; Van Os, 1999a). Therefore, recycling has to be combined with a disinfecting method to avoid the dispersal of root-infecting pathogens.

Among the wide range of available active treatments, UV radiation, pasteurization and chemical treatment (chlorination, ozonization, hydrogen peroxide, etc.) are known to efficiently eliminate pathogens from nutrient solutions; but their drawbacks are the high cost of investments and energy, together with their impact on crops (Ehret et al., 2001). Among other available treatments, slow filtration (SF) is a low-cost technique adapted from drinking water treatment to horticultural production systems in the nineties (Wohanka, 1995). This filtration system has proven to be efficient in the elimination of various pathogens (Ehret et al., 2001; Van Os et al., 1999b). This disinfection process is based on the percolation of a nutrient solution through a column filled with a medium, e.g. fine sand, rockwool flocks or pozzolana particles, where a complex combination of chemical, biological and physical processes takes place (Weber-Shirk and Dick, 1997). To enhance biofiltration efficacy, certain investigations have been aimed at gaining insight into the physics of biofiltration through the determination of parameters such as media, optimal depth of medium in the column and flow rates (Wohanka et al., 1999). More recently, there has been an increase in interest in the microbiology of slow filtration further to the availability in the literature of convincing evidence of the key implication of microorganisms in the filtration process. For instance, Brand and Wohanka (2001) described the colonization of sand by Burkholdaria, Comamonas, Pseudomonas, etc., whose elimination by filter sterilization considerably reduced the elimination of the plant-pathogenic bacteria, Xanthomonas campestris pv. pelargonii. Calvo-Bado et al. (2003) demonstrated that the filtering medium, i.e. sand, of SF provides a large surface area, readily colonized by microorganisms that may be responsible for the removal of Phythophthora zoospores. According to the literature data, Pseudomonas species would dominate the active cultivable bacterial population at the top of the sand filter. From comparisons with a control filter, recent studies have evidenced a very significant enhancement of Fusarium oxysporum

* Corresponding author: patrice.rey@univ-brest.fr 
elimination by inoculation of a filter unit with Pseudomonas putida and Bacillus cereus strains (Déniel et al., 2004; Rey et al., 2005).

The filter used in this 3-year study was a dynamic filter named a "shier biofilter". Compared with classical slow filtration, the specificity of dynamic filtration relies on the pumping of air through the filtering medium (pozzolana particles); moreover, the water and the medium are both in constant motion. These investigations were, first, aimed at assessing, over three cultural seasons, the technique's efficacy not only against potentially pathogenic fungi, but also against bacterial microflora and more specifically against Pseudomonas spp. Moreover, a known limitation of disinfecting techniques being the recontamination of nutrient solution by microorganisms, it seemed to us worth assessing the level of contamination in the disinfected solution storage tank. In other respects, the correlation of filter efficiency with the microbial colonization of the filtering media drove us to estimate the dynamics of bacterial populations on the filtering media. Finally, the goal of disinfection being the protection of plants against pathogens, we estimated its incidence on root colonization by Pythium spp.

\section{MATERIALS AND METHODS}

\subsection{Filter unit}

The filter unit was installed in a greenhouse at room temperature. The effluent solution flowed through a column consisting of a galvanized iron pipe $(150 \mathrm{~cm}$ in length and $220 \mathrm{~cm}$ in inner diameter) filled with pozzolana particles (1-4 $\mathrm{mm}$ in diameter and about 22 tons in weight) as the filtering medium. The filtration rate was in the range of $2-2.5 \mathrm{~m}^{3} /$ hour.

The upper water layer was regulated by a float switch at a height of $20-30 \mathrm{~cm}$ above the pozzolana surface. Pozzolana particles and nutrient solutions were mixed by pumping some air through the filtering material. Depending on the needs of the greenhouse, the filter was either in operation for a few hours every day from March to September because of the active recirculating irrigation system, or stopped from October to February because of a lack of tomato plants. Moreover, to preserve biological activity, the upper pozzolana particles were constantly covered with a water layer during the rest period.

\subsection{Nutrient solution sampling}

The dynamic filter efficacy was determined from regular sampling carried out throughout the cultivation season, i.e. from April to September. Each month, 3 samples of nutrient solution were collected just before it flowed through the filter, 3 others were taken from the filter effluent and the last 3 from the filtered solution stored in the storage tank. The fungal populations of Pythium spp. and Fusarium oxysporum were assessed as well as the total mesophilic aerobic bacteria and fluorescent Pseudomonas, described as key components of roots and nutrient solution microflora in soilless cultures (Berkelman et al., 1994; Rey et al., 1997).

Pythium spp. and F. oxysporum populations were determined on nutrient solution samples filtered through a $0.45-\mu \mathrm{m}$ membrane filter. The filters were plated on selective media denoted CMA-PARP for Pythium spp. and Komada for $F$. oxysporum and incubated at $25^{\circ} \mathrm{C}$ in the dark. Then, Pythium thalli were counted after a 48-hour incubation, whereas $F$. oxysporum propagules were enumerated at days 5 and 7. Results were expressed as Colony Forming Units (CFU)/L of solution and in percent of eliminated fungi.

Each nutrient solution sample was plated with a spiral plater (Intersciences, France) on a selective medium (2 sub-samples per sample), which was either Plate Count Agar (PCA) for the total mesophilic aerobic bacteria or King B agar for fluorescent Pseudomonas. The colonies of bacteria were numbered on plates incubated for 48 hours in the dark, whereas fluorescent Pseudomonas was detected after the same period and counted by irradiation at $366 \mathrm{~nm}$. Results were expressed as CFU/mL of solution and in percent of eliminated microorganisms.

\subsection{Assessment of the bacterial colonies plated on pozzolana particles}

Every year, pozzolana particles were sampled from March to September in order to estimate the bacterial populations responsible for colonization of the filtering medium. Three samples of pozzolana particles were collected from the column every month. The natural microflora settled on the biofilm was assessed as described by Déniel et al. (2004); briefly, $7 \mathrm{~g}$ of pozzolana particles were washed 3 times with $63 \mathrm{~mL}$ of physiological solution $(0.85 \% \mathrm{NaCl})$ and Tween 80 ; then they were sonicated for $90 \mathrm{~s}$ at the highest setting using a VibraCell bench sonicator (Bioblock Scientific, Illkirch, France) to detach the bacterial biofilm. As previously described, the mesophilic bacteria were counted on PCA medium, Bacillus spp. on antibiotics-amended Glucose-Agar (GA) medium, Pseudomonas spp. on Cetrimide-Fucidine-Cefaloridine (CFC) medium and fluorescent Pseudomonas on King B medium. Results of bacterial species were expressed as the number of CFUs per gram of pozzolana particles.

\subsection{Tomato culture in a commercial soilless greenhouse}

The 3 varieties of tomato plants used for this 3-year survey were Allura for the first year, Camaro for the second year and Lemance for the last year. They were planted in coco-fiber slabs and fertilized daily with a nutrient solution. Each slab was isolated from the others with a plastic bag.

The nutrient solution circulated in a closed loop within the greenhouse and was delivered to each plant through a capillary system installed at its collar. Its $\mathrm{pH}$ and temperature were regularly controlled in order to, respectively, fall within 5.5-6.2 and $16-25^{\circ} \mathrm{C}$ (day/night).

\subsection{Root colonization by Pythium spp. in soilless culture}

Every year, in March, April, May, June and September, three samples of tomato roots were collected from plants growing in the greenhouse. Three grams of roots were then aseptically 
Table I. Three-year assessment of dynamic filter efficacy for Pythium spp. removal.

\begin{tabular}{|c|c|c|c|c|}
\hline & April & May & June & September \\
\hline \multicolumn{5}{|l|}{ First year } \\
\hline Influent solution & 120 & 140 & 133 & 110 \\
\hline Effluent solution & 0 & 1 & 1 & 1 \\
\hline$\%$ elimination & 99.9 & 99.2 & 99.2 & 99.0 \\
\hline stock solution & 3 & 21 & 21 & 20 \\
\hline \multicolumn{5}{|l|}{ Second year } \\
\hline Influent solution & 138 & 98 & 138 & 112 \\
\hline Effluent solution & 0 & 0 & 0 & 0 \\
\hline$\%$ elimination & 99.9 & 99.9 & 99.9 & 99.9 \\
\hline stock solution & 3 & 17 & 5 & 19 \\
\hline \multicolumn{5}{|l|}{ Third year } \\
\hline Influent solution & 47 & 55 & 128 & 137 \\
\hline Effluent solution & 0 & 0 & 0 & 0 \\
\hline$\%$ elimination & 99.9 & 99.9 & 99.9 & 99.92 \\
\hline stock solution & 2 & 0 & 9 & 12 \\
\hline
\end{tabular}

Note: Pythium spp. thalli were counted (in CFU/mL) on a selective medium denoted CMA-parp after a 48-hour incubation of the plates at $25{ }^{\circ} \mathrm{C}$ in the dark. Results are expressed in percent of eliminated microorganisms.

transferred to a stomacher bag and rocked for 30 seconds in $100 \mathrm{~mL}$ of a sterile solution of physiological water $(0.85 \%$ $\mathrm{NaCl}$ ) and Tween 80. These suspensions were plated in duplicate on CMA PARP selective medium and left for $48 \mathrm{~h}$ at $25^{\circ} \mathrm{C}$ in the dark prior to the enumeration of Pythium spp.; results were expressed as CFU per gram of root.

\subsection{Statistical Analysis of the results}

Experimental data were statistically analyzed with Duncan's multiple range test at a $P=0.05$ level of confidence by StatGraphics, release 4.0. statistical package (Manugistic Inc., Rockville, USA).

\section{RESULTS AND DISCUSSION}

\subsection{Efficiency of 3-year shier-biofiltration in soilless cultivation}

Whatever the sampling month, the recirculating solutions used in the soilless culture contained Pythium spp. and F. oxysporum. During the cultural season, the fungal concentration in the influent solution varied markedly (Tabs. I, II). F. oxysporum were isolated at a higher density than Pythium spp., 180-3000 CFU/L and 47-140 CFU/L, respectively. Since these fungi are known to be potentially pathogenic for plants and ubiquitous in soilless cultures, their control is an absolute prerequisite for plant safety.

Table I shows that more than $99 \%$ of Pythium spp. were eliminated over the 3 years of the follow-up by flowing the nutrient solution through the dynamic biofilter. In May, June and September of the first year, Pythium spp. were isolated in the effluent solution at a density of $1 \mathrm{CFU} / \mathrm{L}$; it is worth recalling that in the other months no thalli were counted on selective media. The data in Table I shows the very good efficacy and stability over time of dynamic filtration at eliminating zoosporic fungi. To our knowledge, such a long assessment of filter efficacy with no change in conditions for filter maintenance is the first study of this kind to be reported in the literature. Dynamic filtration is a reliable method and provides results which are at least identical to, or better than those obtained with the classical slow filtration systems (Déniel et al., 2004; Ehret et al., 2001; Rey et al., 1999). However, Table II indicates that dynamic filtration was less efficient at $F$. oxysporum elimination, with rates of removal in the range 92.7-99.3\% under the same conditions of tomato production as previously. Colonies of F.oxysporum were generally detected at low concentration ( 3 to $87 \mathrm{CFU} / \mathrm{L}$ ) in the effluent solution. The finding of $F$. oxysporum in effluent solutions contrarily to Pythium spp. made us wonder about its transportation along the column and potential ability to put the plants at risk of fungal attack. However, the lack of plant attack by $F$. oxyporum over the 3-year follow-up suggests that this pathologic risk is very low. The variability observed in $F$. oxysporum elimination may come from: (i) the use of pozzolana particles as a filtering medium, since Wohanka et al. (1999) have shown some correlation between media and filter efficacy, and (ii) the constant motion of water within the column induced by air pumping, which shortened the duration of contact between the biofilm upon pozzolana particles and $F$. oxyporum. The very high and constant efficacy demonstrated by dynamic filtration in Pythium elimination with respect to $F$. oxysporum suggests that a prerequisite to the selection of a filtering medium is to consider the expected pathological risks. Another solution for a full 
Table II. Three-year assessment of dynamic filter efficacy for Fusarium oxysporum elimination.

\begin{tabular}{|c|c|c|c|c|}
\hline & April & May & June & September \\
\hline \multicolumn{5}{|l|}{ First year } \\
\hline Influent solution & $1.810^{3}$ & $1.710^{3}$ & $1.810^{3}$ & $1.810^{2}$ \\
\hline Effluent solution & 87 & 40 & 23 & 7 \\
\hline$\%$ elimination & 95.2 & 97.6 & 98.7 & 96.2 \\
\hline stock solution & 107 & 30 & 35 & 30 \\
\hline \multicolumn{5}{|l|}{ Second year } \\
\hline Influent solution & $1.110^{3}$ & $5.510^{2}$ & $3.910^{2}$ & $1.210^{3}$ \\
\hline Effluent solution & 60 & 7 & 3 & 88 \\
\hline$\%$ elimination & 94.6 & 98.7 & 99.2 & 92.7 \\
\hline stock solution & 67 & 17 & 37 & 93 \\
\hline \multicolumn{5}{|l|}{ Third year } \\
\hline Influent solution & $2.710^{3}$ & $310^{3}$ & $110^{3}$ & $110^{3}$ \\
\hline Effluent solution & 27 & 40 & 7 & 57 \\
\hline$\%$ elimination & 99.0 & 98.7 & 99.3 & 94.3 \\
\hline stock solution & 73 & 33 & 8 & 32 \\
\hline
\end{tabular}

Note: F.oxysporum thalli were counted (in $\mathrm{CFU} / \mathrm{mL}$ ) on a selective medium denoted Komada after incubation of the plates for one week at $25^{\circ} \mathrm{C}$ in the dark. Results are expressed in percent of eliminated microorganisms.

Table III. Three-year assessment of dynamic filter efficacy for mesophilic bacteria microflora elimination.

\begin{tabular}{|c|c|c|c|c|}
\hline & April & May & June & September \\
\hline \multicolumn{5}{|l|}{ First year } \\
\hline Influent solution & $8.710^{4}$ & $9.110^{4}$ & $4.010^{4}$ & $2.710^{4}$ \\
\hline Effluent solution & $3.910^{3}$ & $1.010^{3}$ & $1.010^{4}$ & $6.610^{2}$ \\
\hline$\%$ elimination & 95.5 & 98.9 & 75.0 & 97.6 \\
\hline stock solution & $1.010^{4}$ & $1.710^{4}$ & $5.410^{3}$ & $2.710^{3}$ \\
\hline \multicolumn{5}{|l|}{ Second year } \\
\hline Influent solution & $1.610^{5}$ & $3.610^{4}$ & $4.310^{4}$ & $9.110^{4}$ \\
\hline Effluent solution & $1.410^{4}$ & $7.810^{2}$ & $1.610^{3}$ & $4.310^{3}$ \\
\hline$\%$ elimination & 91.2 & 97.8 & 96.3 & 95.3 \\
\hline stock solution & $2.410^{4}$ & $7.110^{3}$ & $3.010^{3}$ & $1.910^{4}$ \\
\hline \multicolumn{5}{|l|}{ Third year } \\
\hline Influent solution & $1.310^{5}$ & $2.110^{5}$ & $3.910^{4}$ & $4.410^{4}$ \\
\hline Effluent solution & $3.610^{3}$ & $2.210^{3}$ & $1.010^{3}$ & $2.010^{3}$ \\
\hline$\%$ elimination & 97.2 & 98.9 & 97.4 & 95.5 \\
\hline stock solution & $1.910^{4}$ & $5.410^{3}$ & $1.310^{3}$ & $1.810^{3}$ \\
\hline
\end{tabular}

Note: The number of bacteria in the solution was counted (in CFU/mL) on a selective medium denoted PCA after a 48-hour incubation of the plates at $25^{\circ} \mathrm{C}$ in the dark. Results are expressed in percent of eliminated microorganisms.

elimination of Pythium spp. and/or F. oxysporum over a complete cultural season is the introduction of selected suppressive bacteria in the filtering column, as demonstrated by Déniel et al. (2004) and Rey et al. (2005) for slow filtration. This assumption has been supported by preliminary results obtained with the shier biofilter (unpublished data).
Concerning the removal of bacteria, high concentrations of the mesophilic aerobic microflora were recovered from the recirculating nutrient solution. The range of bacterial population in the influent solution was $3.610^{4}-2.110^{5} \mathrm{CFU} / \mathrm{mL}$ (Tab. III). Elimination rates were high and in the range 91.2$98.9 \%$; the lowest value $(75.0 \%)$ was recorded in the first year 


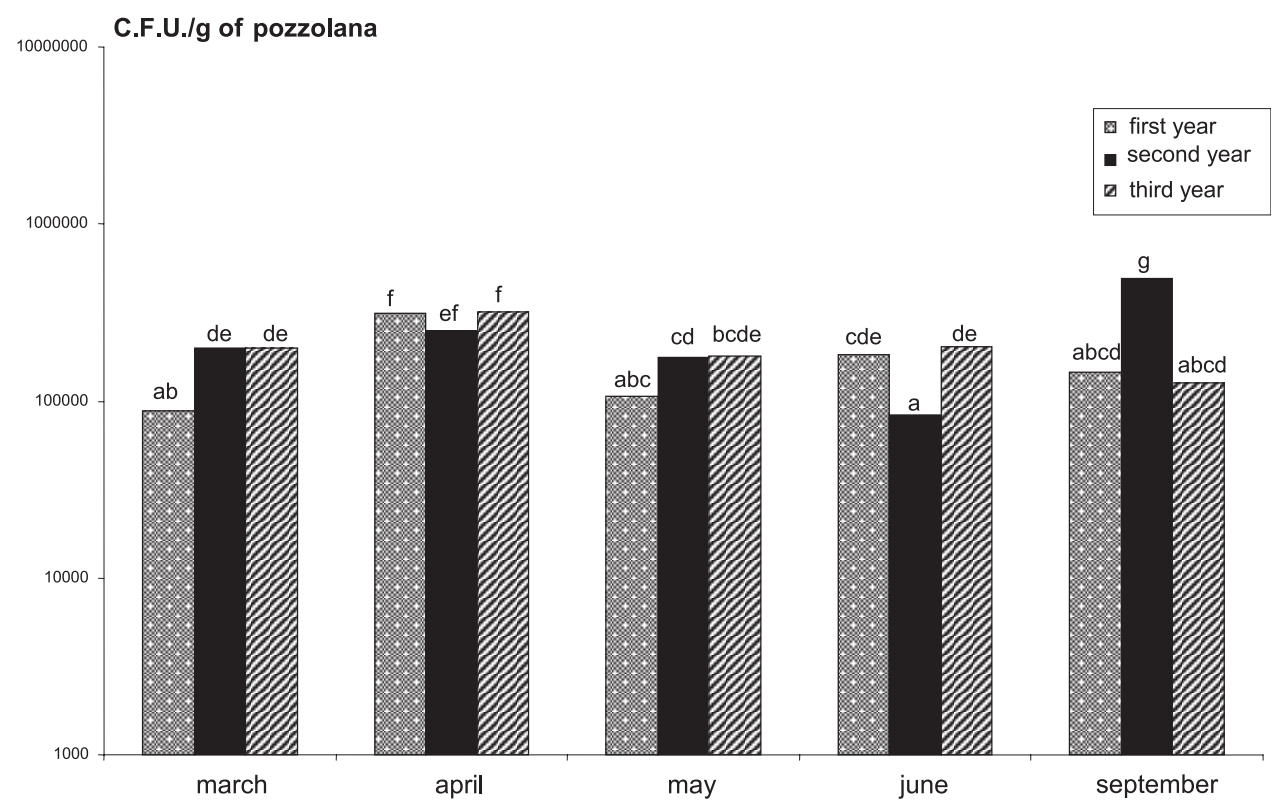

Figure 1. Evolution over three years of the mesophilic bacteria microflora on pozzolana particles from a dynamic filter. The same letter on the bars indicates no significant difference at $P=0.05$ (Duncan multiple range test).

(June). Despite these high rates of elimination, every year the effluent solution was colonized by $6.610^{2}$ to $1.410^{4} \mathrm{CFU} / \mathrm{mL}$ bacteria; these rather high densities are similar to that reported by Ehret et al. (2001) with a slow filter. The lack of identified disease caused by bacteria over our 3-year follow-up suggests that this microflora is non-pathogenic to plants. However, we wondered whether these microorganisms have a suppressive potential; the question deserves to be investigated. The involvement of fluorescent Pseudomonas in the creation of a suppressive microflora in the rhizosphere has been frequently reported in the literature (Walsh et al., 2001; Weller et al., 2002). In the present study, they accounted for 2 to $9 \%$ of the total cultured microflora and were markedly eliminated (91.8 to $99.5 \%)$ from nutrient solutions (data not shown). Consequently, because of the low densities of fluorescent Pseudomonas (10 to 247 CFU/ $\mathrm{mL}$ ) in the effluent solutions, their effect on the establishment of a beneficial microflora in the rhizosphere seems questionable. Very few experiments have been performed on the characterization of the other microorganisms involved in the colonization of effluent solutions; Postma et al. (1999) have reported the occurrence of a shift in the microflora when nutrient solutions flowed along a slow filtering column. Single Strand Conformation Polymorphism allowed us, recently, to show that all of the total bacterial populations were concerned by this shift over the whole cultural season (unpublished data). However, evidence of the involvement of specific bacteria species in the creation of a suppressive microflora, at first in nutrient solutions, and then in the rhizosphere is still missing.

\subsection{Evolution of bacterial populations on pozzolana particles over the 3-year follow-up}

Throughout this 3-year experiment, the pozzolana particles were highly colonized by various Gram-positive and Gram- negative bacteria from the mesophilic aerobic microflora. As suggested by Wohanka et al. (1995), the filter medium was likely biologically activated by the recirculating nutrient solution, which provided more than $10^{4} \mathrm{UFC} / \mathrm{mL}$ of micro-organisms in suspension. Each year, and depending on the month of analysis, the density of bacterial populations on the pozzolana particles varied from $8.410^{4}$ to $4.910^{5} \mathrm{CFU} / \mathrm{g}$ (Fig. 1) with some significant increase or decrease. Once again, these marked variations likely resulted from the type of biofiltration; here, by creating a constant flow of water together with a mixing of pozzolana particles, the pumping of air through the column likely prevented the uniform growth of a bacterial biofilm like the one that would have been observed on a stable surface. This observation differs from data on slow filtration: indeed, a stabilization of bacterial populations on the top layer of a column was evidenced after a 1-month filtration (Calvo-Bado et al., 2003) and the bacterial population was found to stay at the same level throughout the whole cultural season (Déniel et al., 2004). As indicated above, these differences in filter media colonization likely rely on bacterial development either in a stable (slow filtration) or changing (shier biofilter) environment.

We assessed the populations of Pseudomonas and Bacillus because of their proven impact on filter efficacy. The former was always detected on the pozzolana particles even though the density of Pseudomonas populations varied with time from $2.810^{4}$ to $2.710^{5}$ C.F.U./g (Fig. 2). Over 8 out of the 15 sampling months, they accounted for $50 \%$, or even more, of the total cultured bacteria. Usually, at least half of the Pseudomonas populations were fluorescent Pseudomonas; their assessment on grains was variable and similar to that of Pseudomonas spp. (data not shown). Thus, whatever the type of filtration, shierbiofilter or slow-filter, Pseudomonas populations were predominant. With a sand column, Calvo-Bado et al. (2003) 


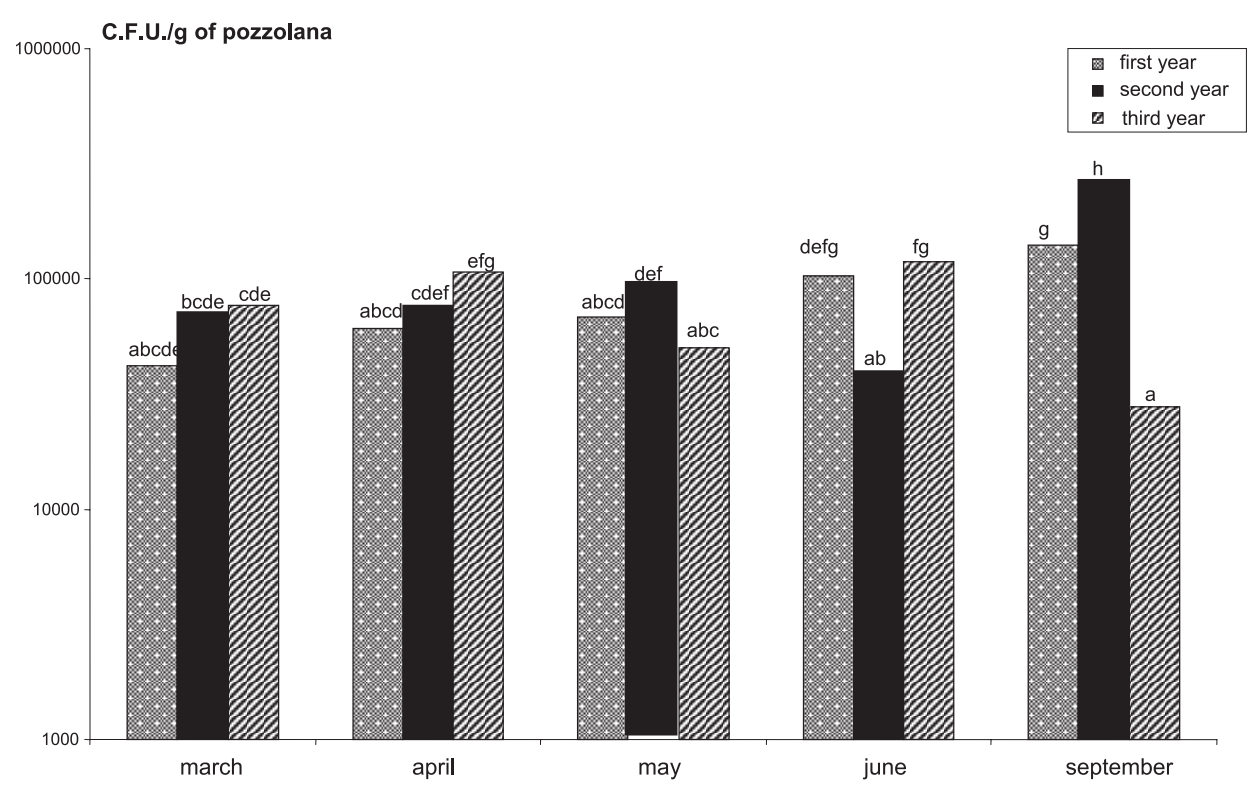

Figure 2. Evolution over three years of Pseudomonas spp. populations on pozzolana particles from a dynamic filter. The same letter on the bars indicates no significant difference at $P=0.05$ (Duncan multiple range test).

observed the development of large microbial populations at the top of the filter, together with an apparent dominance of Pseudomonas species over the cultivable populations; this larger population may be related to a higher concentration in the particulate organic carbon known to accumulate in the upper layers of the sand filter. Here, with a dynamic biofilter, the airflow induced a constant mixing of pozzolana particles and water with neither a stable top layer nor an accumulation of organic nutrients; on the other hand, we also observed a predominance of Pseudomonas among the cultivable microbial populations. Concerning the role of Pseudomonas on filter efficacy, it is worth noting that various organic compounds, e.g. amino acids, are degraded by fluorescent Pseudomonas frequently isolated from most temperate soils, waters or slow filters. Alsanius et al. (1998) reported that Pythium spp. can specifically metabolize amino acids; therefore, one can assume that nutrient competition for amino acids between Pseudomonas spp. and Pythium spp. may also be a way of action for fungal elimination in the shier biofilter.

Populations of the Bacillus genus were less significant than Pseudomonas ones. With the exception of the 3 months when they accounted for about 20 to $30 \%$ of the total cultured bacteria, they constituted less than $10 \%$ of the total cultured microflora. Depending on the sampling month, the population density varied from 1 to $1.510^{4} \mathrm{CFU} / \mathrm{g}$ (data not shown). According to Déniel et al. (2004), though being generally low in slow-filter media, populations of Bacillus spp. regularly increase because of their proven ability to colonize grains already invaded by other bacteria. No increase in Bacillus populations versus time was observed in this study; we wondered whether the high variability in Bacillus population density resulted from the permanent motion of grains in the shier biofilter, responsible for conditions unfavorable to a regular growth of Bacillus. Although Bacillus populations are low, it has frequently been reported that these micro-organisms had an importance and a certain incidence on the biofiltration effec- tiveness (Déniel et al., 2004). The best supporting evidence is that Bacillus spp. are known to produce a variety of antimicrobial substances which adversely affect numerous bacteria and fungi (Chérif et al., 2002; Edwards et al., 1994).

\subsection{Bacterial and fungal recontamination of filtered solution in the storage tank}

After the flowing of nutrient solution through the filter unit, a resident bacterial and fungal microflora was regularly detected in the storage tank throughout the 3-year monitoring (Figs. 3, 4). Microbial populations were usually lower in the stock solution than in the influent one because of their efficient elimination by dynamic biofiltration. No recontamination of fluorescent Pseudomonas and F. oxysporum was observed, whereas the concentration of Pythium spp. was slightly increased in the storage tank (Fig. 3). The total bacterial microflora remained at densities of $10^{3}$ and $10^{4} \mathrm{CFU} / \mathrm{mL}$ in the effluent and stock solutions, respectively (Fig. 4). Together, these experimental data underline that, among bacteria, it is paramount to identify those found at the highest densities in the storage tank. The lack of bacteria-induced pathological diseases over the 3-year monitoring suggests that they are either neutral or beneficial to plants. Their determination should be helpful to gain more insight into their role in disease suppression of recirculating nutrient solutions.

\subsection{Pythium root colonization in the soilless greenhouse}

Figure 5 shows the occurrence of a significant, but late, root colonization by Pythium spp. over the cultural season; the same thing was observed over the 3 consecutive years. Very few thalli of Pythium spp. were detected in the rhizosphere of plants growing in coco-fibers from March to June. This low concentration was also related to the absence of root necrosis. These 


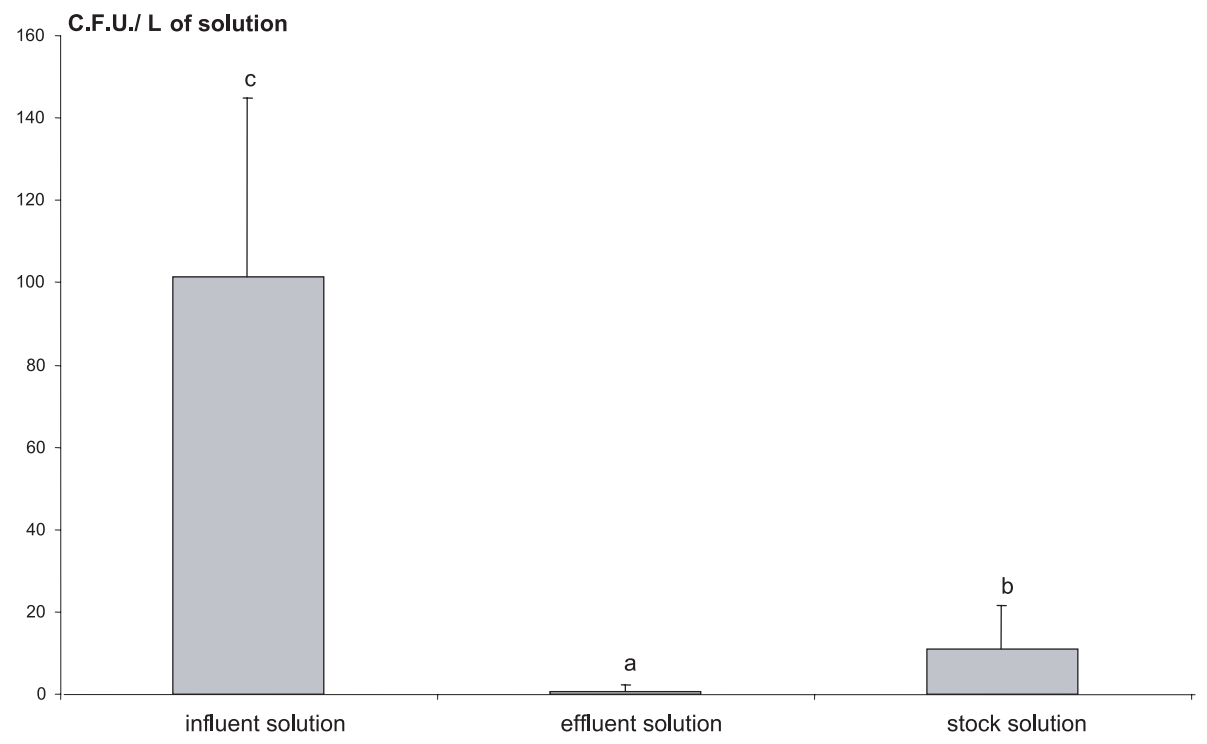

Figure 3. Average of dynamic filter efficiency on Pythium spp. after a three-year period of study. The same letter on the bars indicates no significant difference at $P=0.05$ (Duncan multiple range test).

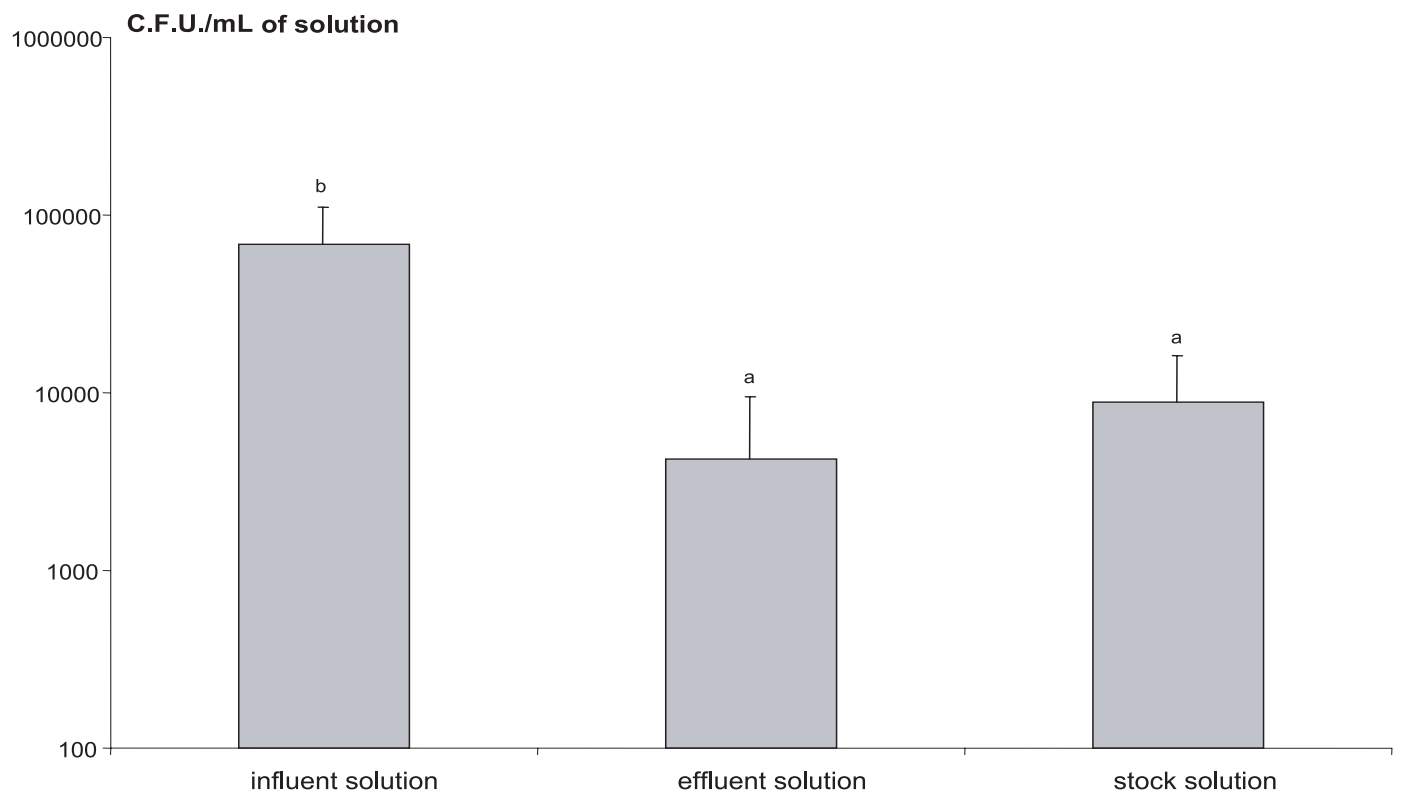

Figure 4. Average of dynamic filter efficiency on mesophilic bacteria microflora after a three-year period of study. The same letter on the bars indicates no significant difference at $P=0.05$ (Duncan multiple range test).

fungi were usually found in September at concentrations higher than $10^{3} \mathrm{CFU} /$ gram of roots. The enhancement of root colonization by Pythium spp. observed at the end of each cultural season was associated with the development of root rot. According to the literature, Pythium infections frequently induce disease and yield losses in tomato soilless cultures (Rey et al., 1997; Stanghellini and Rasmussen, 1994). In the present study, the use of the nutrient solution in a closed circuit in spring and midsummer had no pathogenic incidence on roots; by drastically eliminating Pythium spp., the shier biofilter was likely involved in this root protection. Another factor, which remains to be determined, is the role played by the potentially beneficial and effluent-transported bacterial microflora in the prevention of Pythium infection on roots. 

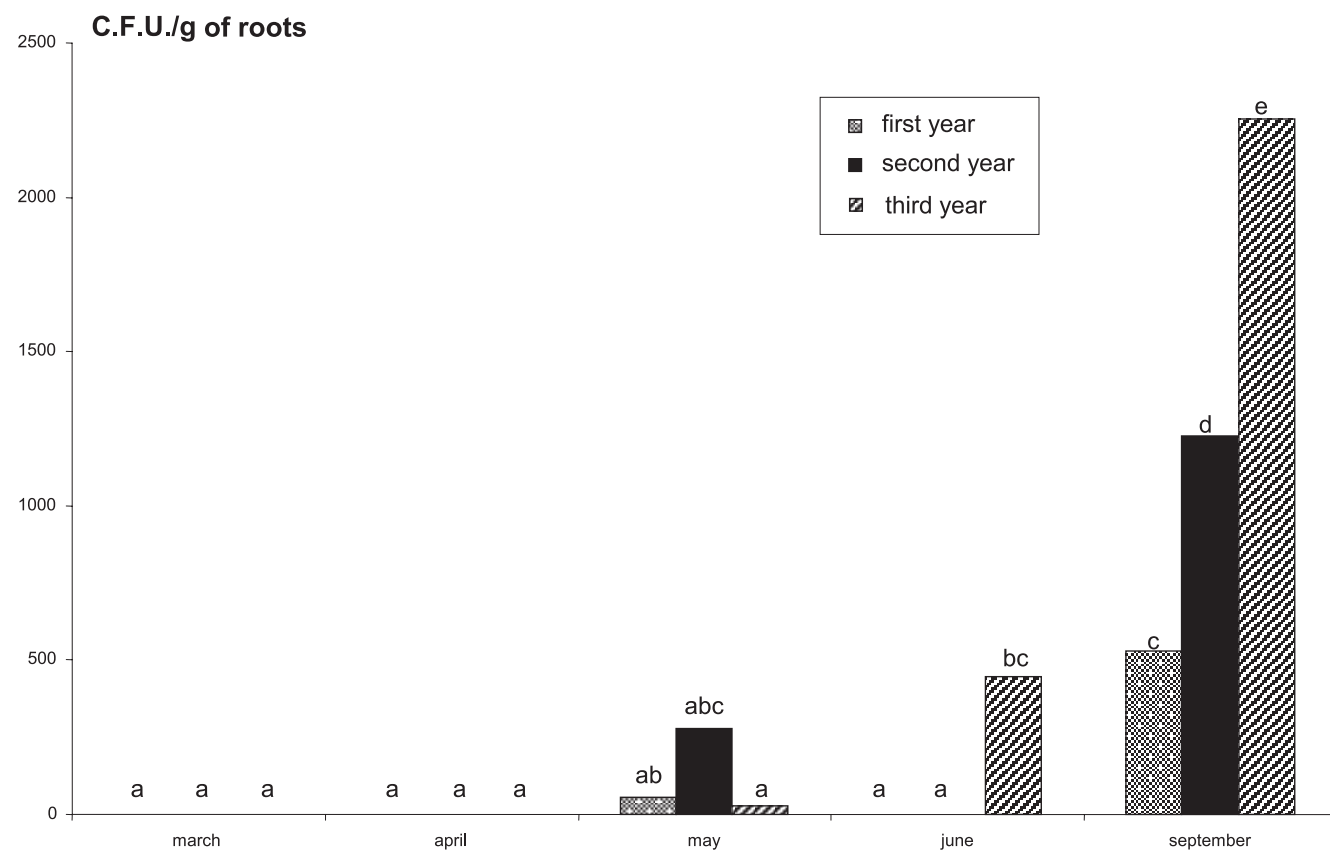

Figure 5. Assessment over three years of Pythium spp. root colonization. The same letter on the bars indicates no significant difference at $P=$ 0.05 (Duncan multiple range test).

\section{CONCLUSION}

This 3-year study evidenced the high efficiency of dynamic biofiltration against potentially pathogenic fungi and showed that it was related to the biological activity of the significant microbial colonization always detected on the moving pozzolana particles composing the filtering medium. The biofilms were partly constituted of Bacillus spp. and Pseudomonas spp., which likely exhibit antagonistic properties for the removal of microorganisms. Further experiments are needed to gain insight into the nature of the microbial interactions on the filter media.

One of the main features of dynamic biofiltration is that most of the bacterial populations are driven to plants by the nutrient solutions. The suppressive potential of these microorganisms detected in effluent solutions is worth considering. Their characterization should be helpful to determine how to favor the establishment of a suppressive microflora in the nutrient solution, and subsequently in the rhizosphere. In the future this lowcost technique based on microbial elimination by physical and biological factors should allow growers to exert a pesticide-free control of pathogens. Biofiltration can also be included in integrated pest management programs aimed at protecting plants against pathogens. Within this context, investigations aimed at promoting the use of dynamic biofiltration in order to eliminate pathogens and drive beneficial bacterial populations to plants are a must for a sustainable cultivation of tomatoes in greenhouses.

Acknowledgements: This research work was financially supported by the Finistère General Council. We thank Dr M.P. Friocourt and Dr B.A. Mohammadou for critical discussion of this work. We also thank Mr Hascoët André for hosting part of the experiments in his greenhouse in Saint Pol de Léon (France).

\section{REFERENCES}

Alsanius B.W., Khalil S., Hultberg M. (1998) Biochemical and chemical characterization of Pythium ultimum, Med. Fac. Landbouww. Univ. Gent. 63/3, 91-897.

Berkelman B., Wohanka W., Wolf G.A. (1994) Characterization of the bacterial flora in circulating nutrient solutions of a hydroponic system with rockwool, Acta Hort. 361, 371-381.

Brand T., Wohanka W. (2001) Importance and characterization of the biological component in slow filters, Acta Hort. 554, 313-321.

Calvo-Bado L.A., Petit T.R., Parsons N., Petch G.M., Morgan J.A.W., Whipps J.M. (2003) Spatial and temporal analysis of the microbial community in slow sand filter used for treating horticultural irrigation water, Appl. Environ. Microbiol. 69, 2116-2125.

Chérif M., Sadfi N., Benhamou N., Boudabbous A., Boubaker A., Hajlaoui M.R., Tirilly Y. (2002) Untrastructure and cytochemistry of in vitro interactions of the antagonistic bacteria Bacillus cereus $\mathrm{X} 16$ and $B$. thuringiensis $55 \mathrm{~T}$ with Fusarium roseum var. sambucinum, J. Plant Pathol. 84, 83-93.

Déniel F., Rey P., Chérif M., Guillou A., Tirilly Y. (2004) Inoculation of filter unit with antagonistic- and PGPR-bacteria improve slow filtration efficiency in soilless culture, Can. J. Microbiol. 50, 499-508.

Edwards S.G., McKay T., Seddon B. (1994) Interaction of Bacillus species with phytopathogenic fungi - Methods of analysis and manipulations for biocontrol purposes, in: Blakeman J.P., Williamson B. (Eds.), Ecology of plant pathogens, Wallingford, CAB International, pp. 101-118.

Ehret D.L., Alsanius B., Wohanka W., Menzies J.G., Utkhede R. (2001) Disinfestation of recirculating nutrient solutions in greenhouse horticulture, Agronomie 21, 323-339.

McPherson G.M., Harriman M.R., Pattison D. (1995) The potential for spread of root diseases in recirculating hydroponic systems and their control with disinfection, Med. Fac. Landbouww. Univ. Gent. 60/2b, 371-379. 
Postma J., Van Os E.A., Kritzman G. (1999) Prevention of root diseases in closed soilless growing systems by microbial optimization, Med. Fac. Landbouww. Univ. Gent. 64/3b, 431-440.

Rey P., Déniel F., Guillou A., Le Quillec S. (2005) Management of bacteria to improve slow filtration efficiency in tomato soilless culture, Acta Hort. 691, 349-356.

Rey P., Nodet P., Tirilly Y. (1997) Pythium F induce a minor but ubiquitous disease in tomato soiless cultures, J. Plant Pathol. 79, 173180.

Rey P., Picard K., Déniel F., Benhamou N., Tirilly Y. (1999) Development of an IPM system in soilless culture by using slow sand filtration and a biocontrol agent, Pythium oligandrum, IOBC wprs Bull. 22, 205-208.

Stanghellini M.E., Rasmussen S.L. (1994) Hydroponics, a solution for zoosporic pathogens, Plant Dis. 78, 1129-1138.

Van Os E.A. (1999a) Closed soilless growing systems: a sustainable solution for dutch greenhouse horticulture, Water Sci. Technol. 39, $105-115$.
Van Os E.A., Amsing J.J., van Kuik A.J., Willers H. (1999b) Slow sand filtration: a potential method for the elimination of pathogens and nematodes in recirculating nutrient solutions from glasshousegrown crops, Acta Hort. 481, 519-526.

Walsh U.F., Morrissey J.P., O'Gara F. (2001) Pseudomonas for biocontrol of phytopathogens: from functional genomics to commercial exploitation, Curr. Opin. Biotechnol. 12, 289-295.

Weber-Shirk M.L., Dick R.I. (1997) Physical-chemical mechanisms in slow sand filters, J. Am. Water Works Assoc. 89, 87-100.

Weller D.M., Raaijmakers J.M., McSpadden Gardener B.B., Thomashow L.S. (2002) Microbial populations responsible for specific soil suppressiveness to plant pathogens, Annu. Rev. Phytopathol. 40, 309348 .

Wohanka W. (1995) Disinfection of recirculating nutrient solution by slow sand filtration, Acta Hort. 382, 246-255.

Wohanka W., Luedtke H., Ahlers H., Luebke M. (1999) Optimization of slow filtration as a means for disinfecting nutrient solutions, Acta Hort. 481, 539-544. 